\title{
PALYNOLOGICAL INVESTIGATIONS IN THE OLD TOWN OF HELSINKI
}

\author{
IRMELI VUORELA
}

VUORELA, IRMELI 1994: Palynological investigations in the old town of Helsinki. Bull. Geol. Soc. Finland 66, Part 2, 125-128

The main sites and palynological results obtained in 1989-1993 in connection with archaeological excavation in the Old Town of Helsinki, are briefly reported. The pollen analytical investigations focused on the cultural layer dating to approximately AD 1400-1700, on two former water wells, on the local river bed and on the bottom deposits of a former ditch while microfossil analysis was mainly made on the material from waste pits, wells and house areas. The results previously published confirm the interpretation made on corresponding material in other medieval towns of Finland.

Key words: paleoecology, archaeological sites, urban environment, pollen analysis, phytoliths, macrofossils, Medieval, Helsinki, Finland.

Irmeli Vuorela, Geological Survey of Finland, FIN-02150 Espoo.

\section{INTRODUCTION}

In the period 1989-1993 excavations were carried out by the Helsinki City Museum in the Old Town of Helsinki which in 1550-1640 was situated at the estuary of the River Vantaa, about $5 \mathrm{~km}$ north of the present centre of Helsinki. In pre-urban time the village of Koskela was located in the same area but for that period almost all historical documents are lacking. Samples for archaeometrical investigations were taken during the excavations and the results have been presented in unpublished reports (see below) and also published in international journals (Vuorela \& Lempiäinen 1993). The palynological and palaeobotanical results have also been given a whole room in the public 3-year-exhibition of the 
Helsinki City Museum which opened in October 1993. For relevant literature, reference should be made to the articles mentioned above and the literature therein.

\section{RESULTS}

The investigations focused on the following aspects:

1. The cultural layer (Vuorela 1989). Several sites in the Old Town area have been investigated by means of pollen analysis.

The material investigated proved to be divided into a lower, rural and an upper, urban part. Historical documents date the boundary between the two to AD 1550. Extremely low Pinus and Picea pollen frequencies are characteristic of the tree pollen data. The rural part was characterized by relatively few pollen taxa with low Cerealia and weed pollen frequencies and high Poaceae pollen frequencies. Cichoriaceae values increase towards the urban layers and pollen concentration values decrease.

The urban and post-urban layers contain many more pollen taxa of which Cichoriaceae frequences dominate, exceeding even those of Poaceae. The Cerealia pollen frequencies, especially those of Secale increase, probably as a result of storage of and/or trade in cereals (cf. Greig 1982). Of the other urban indicators Brassicaceae, Chenopodiaceae and Centaurea cyanus should be mentioned. The low Secale/Centaurea cyanus ratio points to the possibility that the latter species has been cultivated separately inside the town area.

Special features of the urban part of the profile are as follows:

-the lowest pollen concentration values, -a clear decrease in the AP/NAP ratio, -a sudden increase in Secale in spite of the cessation of Centaurea cyanus occurrences, -maximal values for Chenopodiaceae, -a decrease in Sphagnum and Equisetum.

Correspondingly, the main features in the early post-urban layers are as follows:

- a somewhat higher AP/NAP ratio than in the urban part of the profile, -increased pollen frequencies of Pinus and Picea in relation to those of the deciduous trees,

-constantly high frequencies of Cichoriaceae pollen (Liguliflorae),

-higher pollen concentration values following the extremely low values in the preceding urban level.

The results obtained were comparable with those from Lake Mätäjärvi in the Post-Medieval town of Turku (Vuorela 1985). In later investigations in Porvoo (Vuorela \& Hiekkanen 1991) and Käkisalmi (Vuorela et al. 1992) these features were confirmed as typical of post-medieval urban cultural layers in Finland.

2. Two former water wells. The fill-up material of one well was investigated by means of phytolith analysis (Vuorela 1990a) and the bottom deposits and the fill-up material of the other by means of pollen, phytolith and macrofossil analyses (Vuorela 1991 and the appendix of Lempiäinen therein, Vuorela \& Lempiäinen 1993). The age of the latter well was confirmed by ${ }^{14} \mathrm{C}$-dates (Kankainen 1992).

Phytolith analysis was used for the first time in a Finnish archaeometrical context. When identifying phytoliths the morphotypes determined by Powers etal. (1989) were used. The results indicate changing ecological factors around the wells.

In the bottom deposits the division between the rural and urban parts resembles that found in the terrestrial cultural layers. The ${ }^{14} \mathrm{C}$-date for wooden constructions in the bottom of one of the wells

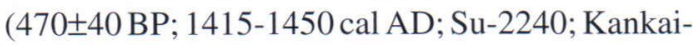
nen 1992) supports the interpretation made on the basis of the pollen data, i.e. that the well had been constructed by the inhabitants of the village of Koskela. The ${ }^{14} \mathrm{C}$-date obtained from the wooden constructions of the other well was $450 \pm 30$ (1430-1450 cal AD; Su-2239; Kankainen 1992). Pollen of Fagopyrum esculentum in the lowermost urban deposits provides evidence for the use of this 
food plant in Old Helsinki; on the basis of earlier results it was also used in Turku, Porvoo and Käkisalmi.

3. Macrofossil analysis of the material sampled from inside former house areas (Lempiäinen 1991b) and radio-carbon dating of the house logs (Kankainen 1991, 1992).

The integration of the results of the macrofossil analysis and the ${ }^{14} \mathrm{C}$-dates of the house logs with the pollen data from the town area added significantly to the information obtained.

4. The pollen and macrofossil content of several waste pits (Vuorela 1990b, 1991, Lempiäinen 1991b, Vuorela \& Lempiäinen 1993).

Even though no stratigraphical succession was expected, the same features as in the cultural layers, especially the high occurences of Cichoriaceae pollen, were recorded (see above). As a result of rapid accumulation, the pollen concentration values remained very low, usually not exceeding 10000 pollen grains $/ \mathrm{cm}^{-3}$.

5. The bottom deposits of a former ditch crossing the area. These were analysed by means of pollen and macrofossil analysis (Vuorela 1990b).

The pollen data obtained from the ditch section indicate that the ditch, together with the older of the two water wells described above, originates from the local rural period. In almost all aspects the pollen flora is similar to that of the cultural layers. The very low frequencies of pollen of coniferous trees, the clear increase in Cichoriaceae pollen at the rural/urban boundary, the relatively high frequencies of Centaurea cyanus etc. are common urban features in most of the pollen diagrams from Helsinki Old Town. Here, it is important to emphasize that this interpretation was confirmed by the ${ }^{14} \mathrm{C}$-dates obtained from the wooden well constructions.

6. A section of the river bed close to the investigation area. This was analysed by means of pollen analysis (Vuorela 1991).

Even in this situation a pollen analytical succession was obtained in which evidence of an opening landscape: increasing settlement indicators and an increasing number of pollen taxa towards the surface samples, seemed to indicate the local settlement history. Since, however, sediments taken from the river bed may have been affected by erosion and/or sediment accumulation, the publication of the results was restricted to a report.

7.The northern part of the research area in the Old Town of Helsinki (1992 investigations). Material for pollen analysis was collected from the wall of the excavation area I-J, from a house area, and from two bottom layers of a 3-m deep and about $1.2 \times 1.2 \mathrm{~m}$ wide pit. The material for macrofossil analysis was collected from the interior area of a house, dated to the late 16th century (Kankainen 1992), from above and around the house area, and from the cultural layers of waste pits and a former cellar (Lempiäinen \& Vuorela 1992).

The pollen analytical results from the house areas did not add to the previous information about the early settlement in Helsinki Old Town. The most interesting results were the finding of seven fig seeds (Ficus carica) from the house areas and the exceptional pollen composition of some dark material - most probably former bottom layers found at a depth of three metres in a pit. The original function of the pit is still unclear to the archaeologists. The high pollen frequencies of Picea and high spore frequencies of Pteridium aquilinum and Polypodiaceae, however, differ clearly from the pollen data obtained from the other sites in the area. They seem to indicate that the pit was, perhaps, used as some kind of animal compound, or even as a gaol where spruce twigs and shoots of Pteridium were used as bedding material. Here, it should be remembered that the pit was located close to the former City square, in the middle of Old Helsinki.

The results referred to above correspond to those 
obtained earlier from the Late-Medieval cultural layers of Turku, Porvoo and Käkisalmi. In Sweden, pollen analytical research has been carried out in the centre of Stockholm (Robertsson et al. 1992). The results strongly emphasize the importance of interdisciplinary research. The interpretation of the pollen and macrofossil results, especially in respect of the previously practically unknown history of the local rural period of time, for instance, is extremely important. They also throw light not

\section{LITERATURE}

\section{Unpublished reports:}

Vuorela, I., 1989. Helsingin Vanhankaupungin kulttuurikerroksen paleoekologinen tutkimus. Geological Survey of Finland, Report KA 43/89/1, 1-37 p.

Vuorela, I., 1990 a. Fytoliittitutkimus Helsingin Vanhankaupungin kulttuurikerroksesta. Geological Survey of Finland, Report KA 43/90/1, 1-31 p.

Vuorela, I., 1990b. Helsingin Vanhankaupungin siitepölyja makrofossiilitutkimukset. Geological Survey of Finland, Report KA 43/90/3, 1-31 p.

Vuorela, I., 1991. Arkeometrisia tutkimuksia Helsingin Vanhassakaupungissa. Appendix 1: Lempiäinen, T. Helsingin Vanhankaupungin makrofossiilitutkimukset. Appendix 2: Kankainen, T.:Helsingin Vanhankaupungin radiohiiliajoitukset. Geological Survey of Finland, Report P 34.4.101, $53+14+10 \mathrm{p}$.

Vuorela, I., 1992. Helsingin Vanhankaupungin siitepölyja makrofossiilidiagrammien kasvilajistoa. Geological Survey of Finland, Report P 34.4.103 1-70 p.

Lempiäinen, T. \& Vuorela, I., 1992. Helsingin Vanhankaupungin vuoden 1992 kaivauksiin liittyvät paleoekologiset tutkimukset. Geological Survey of Finland, Report P 34.4.105, 1-32 p.

Kankainen, T., 1992. Helsingin Vanhankaupungin kahden kaivon jatalon radiohiiliajoitus. Geological Survey of Finland, Report P 35.4.100, 1- 9 p. only upon the local vegetation around the well and on the ditch banks in the village of Koskela, but also on the food plants and the trade connections of the tiny town of Helsinki nearly 500 years ago. This piece of information would never have been achieved by traditional archaeological methods.

ACKNOWLEDGEMENTS: The English manuscript was reviced by Mrs. Sheila Hicks, Ph.D.

\section{Published references:}

Greig, J., 1982. The interpretation of pollen spectra from urban archaeological deposits. In: Hall, A.R., Kenward, H.K. (eds): Environmental Archaeology in the urban context. Counc. Brittish Archaeological Research, Report 43, 47-65.

Powers, A.H., Padmore, J., Gilbertson, D.D., 1989. Studies of Late Prehistoric and modern opal phytoliths from coastal sand dunes and machair in North West Britain. Journal of Archaeological Sciences 16(1), 27-45.

Robertsson, A.-M., Karlsson, S., Aronsson, M., 1992. Fatburssjöns 3000-åriga historia - från bronsålder till 1700-tal. pp. 8-23 in: Fabburen 3000 år. Från en vik i skärgården till Bofills båge. Sigma förlag. 207 p.

Vuorela, I., 1985. The pollen data of Mätäjärvi, Turku, SW Finland. Iskos 5, 247-257.

Vuorela, I. \& Hiekkanen, M., 1991. The urban milieu of the Late-and Post-Medieval town of Porvoo, southern Finland investigated by means of pollen analysis. Annales Botanici Fennici 28, 95-106.

Vuorela, I., A. Saksa, T. Lempiäinen \& Saarnisto, M., 1992.Pollen and macrofossil data on deposits in the wooden fortress of Käkisalmi, dated to about $\mathrm{AD}$ 1200-1700. Annales Botanici Fennici 29, 187-196.

Vuorela, I. \& Lempiäinen T., 1993. Palynological and palaeobotanical investigatons in the area of the post-medieval Helsinki Old Town. Vegetational History and Archaeobotany 2(2), 101-123. 